\title{
Antigenic and Genetic Characterization of Twenty-six Strains of Human Respiratory Syncytial Virus (Subgroup A) Isolated During Three Consecutive Outbreaks in Havana City, Cuba
}

\author{
Angel Valdivia/ ${ }^{+}$, Grehete González, Danay Chacón, Clara Savón, \\ Anselmo Otero, Odalys Váldes, Reynel Cancio, Suset Oropesa, \\ José A Melero*, Blanca García-Barreno*, Angel Goyenechea
}

\author{
Instituto de Medicina Tropical "Pedro Kouri”, Apartado 601, Marianao 13, La Habana, Cuba \\ *Centro Nacional de Biología Fundamental, Madrid, España
}

\begin{abstract}
Twenty-six human respiratory syncytial virus strains (subgroup A) isolated from three outbreaks in Havana City during the period 1994/95, 1995/96 and 1996/97 were analyzed to determine their antigenic and genetic relationships. Analyses were performed by monoclonal antibodies and restriction mapping ( $N$ gene) following amplification of the select region of the virus genome by polymerase chain reaction. All isolated strains were classified as subgroup A by monoclonal antibodies and they showed a restriction pattern NP4 that belonged to subgroup A. Thus the results obtained in this work, showed a close relation (100\%) between antigenic and genetic characterization of the isolated strains in our laboratory. These methods permit the examination of large numbers of isolates by molecular techniques, simplifying the researchs into the molecular epidemiology of the virus.
\end{abstract}

Key words : respiratory syncytial virus - molecular characterization - restriction mapping - monoclonals antibodies

Human respiratory syncytial virus (HRSV) is the major cause of lower respiratory tract infections in infants and young children (McIntosh \& Chanock 1990). This virus is a member of the Pneumovirus genus of the family Paramixoviridae. It has two surface glycoproteins ( $\mathrm{G}$ and $\mathrm{F}$ ), which are the main targets of neutralizing and protective antibodies (Taylor et al. 1984, Walsh et al. 1984).

Variability of HRSV isolates was first demonstrated with hyperimmune serum (Coates et al. 1966). Different panels of monoclonal antibodies were later used to subdivide HRSV isolates into two antigenic groups, A and B (Anderson et al. 1985, Mufson et al. 1985), that correlate with genetically distinct viruses (Cristina et al. 1990). These monoclonals have identified three types of epitopes in the G molecule (García-Barreno et al. 1989, García et al. 1994): (i) variables epitopes, (ii) subgroup specific epitopes, and (iii) conserved

\footnotetext{
This work was funded in part by a grant (BIO95-2066-E) from Comisión Interministerial de Ciencia y Tecnología for Spanish-Cuban cooperation.

${ }^{+}$Corresponding author. Fax: +53-7-246051 and +53-7220633. E-mail: a.valdivia@ipk.sld.cu

Received 26 May 1998

Accepted 9 December 1998
}

epitopes shared by subgroups A and B. The level of antigenic and genetic divergence among the $\mathrm{G}$ glycoproteins of HRSV isolates is the highest reported for an RNA virus gene product (García et al. 1994).

On the other hand the isolates of subgroup A and B of HRSV can be further subdivided into distinct groupings or lineages on the basis of the following criteria: (a) through monoclonal antibodies, (b) restriction mapping of part of the nucleocapsid ( $\mathrm{N}$ Gene), (c) nucleotide sequencing of part of the small hidrophobic (SH) gene and (d) nucleotide sequencing of the attachment $(\mathrm{G})$ protein gene (Cane \& Pringle 1991, 1992, Cane et al. 1992, García et al. 1994, Cane \& Pringle 1995b). These methods allow the speedy analysis of large numbers of samples without the necessity of nucleotide sequencing (Cane \& Pringle 1992).

These lineages appear to be distributed worldwide but as yet their significance in terms of degree of virulence and immunity at the individual and community level has not been determined (Cane \& Pringle 1992).

In this work we combined the use of a panel of monoclonal antibodies and restriction mapping of polymerase chain reaction (PCR) products of the selected region of $\mathrm{N}$ gene to make a complete characterization from $26 \mathrm{HRSV}$ (subgroup A) isolated during three consecutive epidemics in Havana City, Cuba. 


\section{MATERIALS AND METHODS}

Viruses, cells, patients and clinical samples Twenty six nasopharyngeal exudates were obtained from children admitted to the respiratory ward to some of the main pediatric hospitals of Havana City (William Soler, Juan Manuel Márquez and Centro Habana). All samples were suspended in a final volume of $2 \mathrm{ml}$ of minimun essential medium (MEM) containing antibiotics, $(100 \mathrm{U} / \mathrm{ml}$ penicillin and $100 \mu \mathrm{g} / \mathrm{ml}$ streptomycin sulfate). For PCR analysis, $500 \mu \mathrm{l}$ were used in a $1.5 \mathrm{ml}$ tube, and the samples stored at $-70^{\circ} \mathrm{C}$ until being tested. Cell culture and indirect immunofluorescence were conducted according to previously reported procedures (Parrott et al. 1979, Valdivia et al. 1997).

The samples used in this study were from the 15 municipalities forming Havana City.

All RS virus-positive cultures (confirmed by immunofluorescence) were kept at $-70^{\circ} \mathrm{C}$ until further use. Viruses from original isolates (Table) were subcultured two times in HEp- 2 cells, until a cytopathic effect (CPE) was observed within $48 \mathrm{hr}$ after inoculation. At this time, the cells were resuspended in the virus-containing supernatant and were kept as a working seed at $-70^{\circ} \mathrm{C}$.
Dot-Elisa - Characterization of antibody reactivity in Dot-Elisa was done as described by García et al. (1994). Briefly, one plastic flasks (Costar) with a surface area of $75 \mathrm{~cm}^{2}$, containing $20 \mathrm{ml}$ of MEM containing $10 \%$ fetal calf serum, $1 \%$ glutamine, $100 \mathrm{U} / \mathrm{ml}$ penicillin and $100 \mu \mathrm{g} / \mathrm{ml}$ streptomycin sulfate was infected with each of the viruses used in this study. When an extensive CPE was evident by the formation of syncytia, the cells were scraped off with a rubber policeman, pelleted by low-speed centrifugation (3,000 x g, $5 \mathrm{~min})$, and washed with phosphate-buffered saline (PBS). The cell pellets were then resuspended in $300 \mu \mathrm{l}$ of extraction buffer (10 mM Tris- $\mathrm{HCl} \mathrm{pH} 7.6,5$ mM EDTA, $140 \mathrm{mM} \mathrm{NaCl}, 1 \%$ Triton $\mathrm{X}-100$, and $1 \%$ sodium deoxycholate). The extracts were clarified by centrifugation at $10,000 \mathrm{x} \mathrm{g}$ for $5 \mathrm{~min}$ and then were diluted with PBS to $10 \mu \mathrm{g}$ of protein per $\mathrm{ml}$, and $5 \mu \mathrm{l}$ were spotted onto strips of Immobilon paper (Millipore). After air drying, the paper was satured with 5\% skimmed milk in PBS and was revealed with the Mabs indicated in Fig. 1, by using biotinylated antimouse immunoglobulin, streptavidin-peroxidase, and 4-chloro-1-naphthol according to the recommendations of the manufacturer (Amersham Corp). The monoclonal anti-

TABLE

Cuban isolates of human respiratory syncytial virus used in the present study

\begin{tabular}{|c|c|c|c|}
\hline Virus & Date of isolation & Age of patient & Disease \\
\hline $\mathrm{Cub} / 54 / 94$ & $18 / 10 / 94$ & 6 years & URI (ashtma) \\
\hline Cub/60/94 & $20 / 10 / 94$ & 2 months & URI \\
\hline $\mathrm{Cub} / 67 / 94$ & $25 / 10 / 94$ & 3 months & Laringitis \\
\hline $\mathrm{Cub} / 69 / 94$ & $25 / 10 / 94$ & 1 month & URI \\
\hline Cub/81/94 & $01 / 11 / 94$ & 3 months & URI \\
\hline $\mathrm{Cub} / 82 / 94$ & $01 / 11 / 94$ & 4 months & Bronchiolitis \\
\hline $\mathrm{Cub} / 83 / 94$ & $01 / 11 / 94$ & 6 months & Bronchiolitis \\
\hline $\mathrm{Cub} / 97 / 94$ & 08/11/94 & 6 months & Bronchiolitis \\
\hline $\mathrm{Cub} / 105 / 94$ & $15 / 11 / 94$ & 2 months & Bronchiolitis \\
\hline $\mathrm{Cub} / 106 / 94$ & $15 / 11 / 94$ & 5 months & Bronchiolitis \\
\hline $\mathrm{Cub} / 111 / 94$ & $15 / 11 / 94$ & 5 months & Bronchiolitis \\
\hline $\mathrm{Cub} / 115 / 94$ & $17 / 11 / 94$ & not known & URI \\
\hline $\mathrm{Cub} / 128 / 94$ & $01 / 12 / 94$ & 10 months & Bronchiolitis \\
\hline Cub/134/94 & $06 / 12 / 94$ & 3 months & URI \\
\hline $\mathrm{Cub} / 140 / 94$ & $13 / 12 / 94$ & 22 days & URI \\
\hline $\mathrm{Cub} / 141 / 94$ & $13 / 12 / 94$ & 4 months & Bronchiolitis \\
\hline $\mathrm{Cub} / 151 / 94$ & $20 / 12 / 94$ & 5 months & Bronchiolitis \\
\hline $\mathrm{Cub} / 5 / 95$ & $17 / 01 / 95$ & 5 months & URI \\
\hline $\mathrm{Cub} / 8 / 95$ & $17 / 01 / 95$ & 9 months & Bronchiolitis \\
\hline $\mathrm{Cub} / 10 / 95$ & $19 / 01 / 95$ & 5 months & Bronchiolitis \\
\hline $\mathrm{Cub} / 11 / 95$ & $19 / 01 / 95$ & 6 months & Bronchiolitis \\
\hline $\mathrm{Cub} / 104 / 96$ & 02/04/96 & 5 years & URI \\
\hline Cub/195/96 & 08/10/96 & 2 years & Bronchiolitis \\
\hline $\mathrm{Cub} / 201 / 96$ & $11 / 10 / 96$ & 10 months & Bronchiolitis \\
\hline $\mathrm{Cub} / 202 / 96$ & $11 / 10 / 96$ & 10 months & Bronchiolitis \\
\hline $\mathrm{Cub} / 220 / 96$ & 29/10/96 & 3 months & Bronchiolitis \\
\hline
\end{tabular}

URI : upper respiratory infection. 
bodies were used at a dilution of 1:100. These monoclonals were $021 / 1 \mathrm{G}$ and $021 / 21 \mathrm{G}$ (conserved), 021/19G and 021/2G (subgroup specific), and $63 \mathrm{G}, 25 \mathrm{G}, 68 \mathrm{G}, 58 \mathrm{G}, 59 \mathrm{G}, 61 \mathrm{G}, 62 \mathrm{G}, 64 \mathrm{G}$ and 74G ("Long" strains specific)(García-Barreno et al. 1989, García et al. 1994) and they were provided by Prof. JA Melero, Deparment of Molecular Biology, National Center of Microbiology, Virology and Sanitary Immunology, Madrid, Spain. One reference strain of group A (Long) and one of group B ( $\mathrm{CH}$ 18537) were included as negative and positive controls in this work. One HEp-2 extract was also included as negative control.

Nucleic acid extraction from clinical specimens - All small-scale RNA extractions were carried out in $1.5-\mathrm{ml}$ microfuge tubes without any attemp at separating RNA from DNA, using an adaptation of the method of Kumar and Lindberg (1972). Nasopharyngeal exudates samples were centrifuged in a microfuge for $2 \mathrm{~min}$. The cell pellet was resuspended in $0.5 \mathrm{ml}$ of $3.5 \mathrm{M}$ urea, $200 \mathrm{mM} \mathrm{NaCl}$, $10 \mathrm{mM}$ Tris-HCl pH 7.8, $5 \mathrm{mM}$ EDTA, $0.75 \mathrm{mM}$ $\mathrm{MgCl}_{2}, 0.5 \%$ SDS and $0.35 \% \mathrm{NP} 40.0 .5 \mathrm{ml}$ of phenol-chloroform (1:1)(equilibrated with $150 \mathrm{mM}$ $\mathrm{NaCl}, 10 \mathrm{mM}$ Tris-HCl pH 7.8, 1 mM EDTA) was added, the mixture vortexed for about $5 \mathrm{sec}$ and then centrifuged for $10 \mathrm{~min}$. The aqueous layer was extracted again with phenol-chloroform and then added to $1 \mathrm{ml}$ of ethanol; the nucleic acids were precipitated at $-20^{\circ} \mathrm{C}$ for $20 \mathrm{hr}$, pelleted, washed with $0.5 \mathrm{ml} 70 \%$ ethanol, vacuum-dried and resuspended directly into $30 \mathrm{ml}$ reverse transcriptase mix (see below).

RNA extraction from tissue cultures - Virus isolates were cultured in HEp-2 cells in plastic flasks (Costar) with a surface area of $25 \mathrm{~cm}^{2}$, containing $5 \mathrm{ml}$ of MEM with glutamine, penicillin, streptomycin, and $5 \%$ foetal calf serum. When extensive CPE was present, the cells were detached into the tissue culture medium by shaking with sterile glass beads, and the suspension aliquotted and stored at $-70^{\circ} \mathrm{C}$. Approximately $0.5 \mathrm{ml}$ of these infected cell suspensions were extracted as for the nasopharyngeal exudates. The resulting nucleic acids were resuspended in $20 \mu \mathrm{l} \mathrm{H}_{2} \mathrm{O}$ and $3 \mu \mathrm{l}$ used for each cDNA synthesis.

cDNA synthesis and PCR - The preparation of cDNA was carried out with approximate $20 \mu \mathrm{g}$ of total RNA (spectrophotometrically quantified) in a $20 \mu \mathrm{l}$ volume containing $100 \mathrm{ng}$ of each primer. First, the target RNA was mixed with both primers and placed at $65^{\circ} \mathrm{C}$. After $15 \mathrm{~min}$ the solution was placed on ice and completed with $100 \mathrm{mM}$ Tris- $\mathrm{HCl} \mathrm{pH} 8.3,500 \mathrm{mM} \mathrm{KCl}, 25 \mathrm{mM} \mathrm{MgCl} 2$, $25 \mathrm{mM}$ (each) dATP, dCTP, dGTP and dTTP, $20 \mathrm{U}$ Rnasin (Boehringer Mannhein GmbH, Germany) and three units of AMV reverse transcriptase
(Boehringer Mannhein $\mathrm{GmbH}$, Germany). Incubation was at $42^{\circ} \mathrm{C}$ for $30 \mathrm{~min}$. Finally, the reaction mixture was placed at $95^{\circ} \mathrm{C}$ for $5 \mathrm{~min}$ and kept on ice until the PCR was carried out. PCR mix was made up to a volume of $100 \mu \mathrm{l}$, which made a reaction mix containing $100 \mathrm{mM}$ Tris- $\mathrm{HCl} \mathrm{pH} 8.3$, $500 \mathrm{mM} \mathrm{KCl}, 25 \mathrm{mM} \mathrm{MgCl} 2$, distilled water and $2.5 \mu$ Taq DNA polymerase (Boehringer Mannhein $\mathrm{GmbH}$, Germany). The amplification was carrried out in 30 cycles in a Perkin-Elmer Cetus Thermal cycler. Each cycle consisted of denaturation at $93^{\circ} \mathrm{C}$ for $1.5 \mathrm{~min}$, annealing of the primer at $55^{\circ} \mathrm{C}$ for $1.5 \mathrm{~min}$, and chain elongation at $72^{\circ} \mathrm{C}$ for $1.5 \mathrm{~min}$. After the last cycle of amplification, $10 \mu \mathrm{l}$ of the amplified products were analyzed by electrophoresis on $2 \%$ agarose gels with Tris-borate buffer.

Analysis of the amplified products - The remaining products were diluted with $100 \mu \mathrm{l} \mathrm{H}_{2} \mathrm{O}$, extracted with $150 \mu \mathrm{l}$ phenol-chloroform and ethanol precipitated. Samples were then restricted with Pst I, Hae III, Hind III, and Bgl II. All this was performed according to previous reports (Cane \& Pringle 1991, 1992). In these experiments the strain 021, isolated in Uruguay (Montevideo) with an NP5 know pattern was always included as control. This strain was provided by Prof. JA Melero.

Primers - The primers originally designed to amplify between nucleotides 858 and 1135 of the HRSV (N gene)(Collins et al. 1985) have been previously described (Cane \& Pringle 1991):

\section{N1:5'GGAACAAGTTGTTGAGGTTTATGAATATGC3' N2:5'CTTCTGCTGTCAAGTCTAGTACACTGTAGT3'}

Controls - Distilled water, mixed buffer solutions, full-time open vial with final buffer mixture, and HEp-2 RNA were included as negative controls (Stoker 1990, Wright \& Wynford-Thomas 1990, Kitchin \& Bootman 1993). The cDNA reaction and PCR were performed using the recommended strict protocol, with all precautions to prevent contamination (Kwok \& Higuchi 1989).

\section{RESULTS}

Fig. 1, shows the reactivity of Cuban isolates with monoclonal antibodies specific for the $\mathrm{G}$ protein. One reference strain of subgroup A (Long) and one of subgroup B (CH18537) were included in the same assay. All viruses reacted with antibodies that recognized conserved epitopes of the $G$ protein shared by all human isolates. The Cuban isolates reacted with two antibodies $(021 / 2 \mathrm{G}$ ad 021/19G) that recognized different group specific epitopes common to all viruses of antigenic group A (note that $\mathrm{CH} 18537$ did not react with these two antibodies). But the most remarkable fact in the results obtained through this technique is that all strains analyzed reacted against the specific and 


\begin{tabular}{|c|c|c|c|c|c|c|c|c|c|c|c|c|c|}
\hline$A$ & $A$ & I & & & & & & 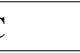 & & & & & \\
\hline 021/1G & $021 / 21 G$ & 021/19G & $21 / 2 \mathrm{G}$ & $63 \mathrm{G}$ & $25 \mathrm{G}$ & $68 \mathrm{G}$ & $58 \mathrm{G}$ & $59 \mathrm{G}$ & $61 \mathrm{G}$ & $62 \mathrm{G}$ & $64 \mathrm{G}$ & $74 \mathrm{G}$ & \\
\hline- & - & - & - & - & - & - & - & - & - & - & - & - & Hep-2 \\
\hline+ & + & + & + & + & + & + & + & + & + & + & + & + & Long \\
\hline+ & + & - & - & - & - & - & - & - & - & - & - & - & CH18537 \\
\hline+ & + & + & + & - & + & + & + & + & + & + & + & + & $54 / 94$ \\
\hline+ & + & + & + & - & + & + & + & + & + & + & + & + & $60 / 94$ \\
\hline+ & + & + & + & - & + & + & + & + & + & + & + & + & $67 / 94$ \\
\hline+ & + & + & + & - & + & + & + & + & + & + & + & + & $69 / 94$ \\
\hline+ & + & + & + & - & + & + & + & + & + & + & + & + & $81 / 94$ \\
\hline+ & + & + & + & - & + & + & + & + & + & + & + & + & $82 / 94$ \\
\hline+ & + & + & + & - & + & + & + & + & + & + & + & + & $83 / 94$ \\
\hline+ & + & + & + & - & + & + & + & + & + & + & + & + & $97 / 94$ \\
\hline+ & + & + & + & - & + & + & + & + & + & + & + & + & $105 / 94$ \\
\hline+ & + & + & + & - & + & + & + & + & + & + & + & + & $106 / 94$ \\
\hline+ & + & + & + & - & + & + & + & + & + & + & + & + & $111 / 94$ \\
\hline+ & + & + & + & - & + & + & + & + & + & + & + & + & $115 / 94$ \\
\hline+ & + & + & + & - & + & + & + & + & + & + & + & + & $128 / 94$ \\
\hline+ & + & + & + & - & + & + & + & + & + & + & + & + & $134 / 94$ \\
\hline+ & + & + & + & - & + & + & + & + & + & + & + & + & $140 / 94$ \\
\hline+ & + & + & + & - & + & + & + & + & + & + & + & + & $141 / 94$ \\
\hline+ & + & + & + & - & + & + & + & + & + & + & + & + & $151 / 94$ \\
\hline+ & + & + & + & - & + & + & + & + & + & + & + & + & $5 / 95$ \\
\hline+ & + & + & + & - & + & + & + & + & + & + & + & + & $8 / 95$ \\
\hline+ & + & + & + & - & + & + & + & + & + & + & + & + & $10 / 95$ \\
\hline+ & + & + & + & - & + & + & + & + & + & + & + & + & $11 / 95$ \\
\hline+ & + & + & + & - & + & + & + & + & + & + & + & + & $104 / 96$ \\
\hline+ & + & + & + & - & + & + & + & + & + & + & + & + & $195 / 96$ \\
\hline+ & + & + & + & - & + & + & + & + & + & + & + & + & 201/96 \\
\hline+ & + & + & + & - & + & + & + & + & + & + & + & + & $202 / 96$ \\
\hline+ & + & + & + & - & + & + & + & + & + & + & + & + & $220 / 96$ \\
\hline
\end{tabular}

Fig. 1-1: strains from 94/95(21); 2: strain from 95/96(01); 3: strains from 96/97(04); A: conserved monoclonal antibodies; B: group-specific monoclonal antibodies; C: antibodies specific for the Long strain; +: positive; -: negative.

variable monoclonals from strain Long, with the exception of monoclonal 63G, which was the only one that did not react against the strains isolated in our laboratory. With the results obtained with this monoclonal panel it would be inferred that the strains isolated in our laboratory are closely related to Long strain.

Fig. 2 shows the restriction analysis of the PCR products obtained from each of the strains belonging to the first outbreak. The restriction analysis of strains 105/94, 106/94 and 128/94 were carried out in another gel (data not shown). The digestion was only made with enzymes $B g I$ II and Hind III, since they had already been classified as members of the subgroup A, by means of monoclonals correspondent.

Fig. 3 shows the restriction analysis from the PCR products obtained from each of the strains belonging to the second and third outbreaks. All strains analyzed by this method turned out to belong to a pattern NP4, which, in previous studies has been reported as the pattern in strains Long, $\mathrm{A}_{2}$ and $\mathrm{RSS}_{2}$ (Cane \& Pringle 1991, 1992). Furthermore, all products from PCR and from each of the strains analyzed 


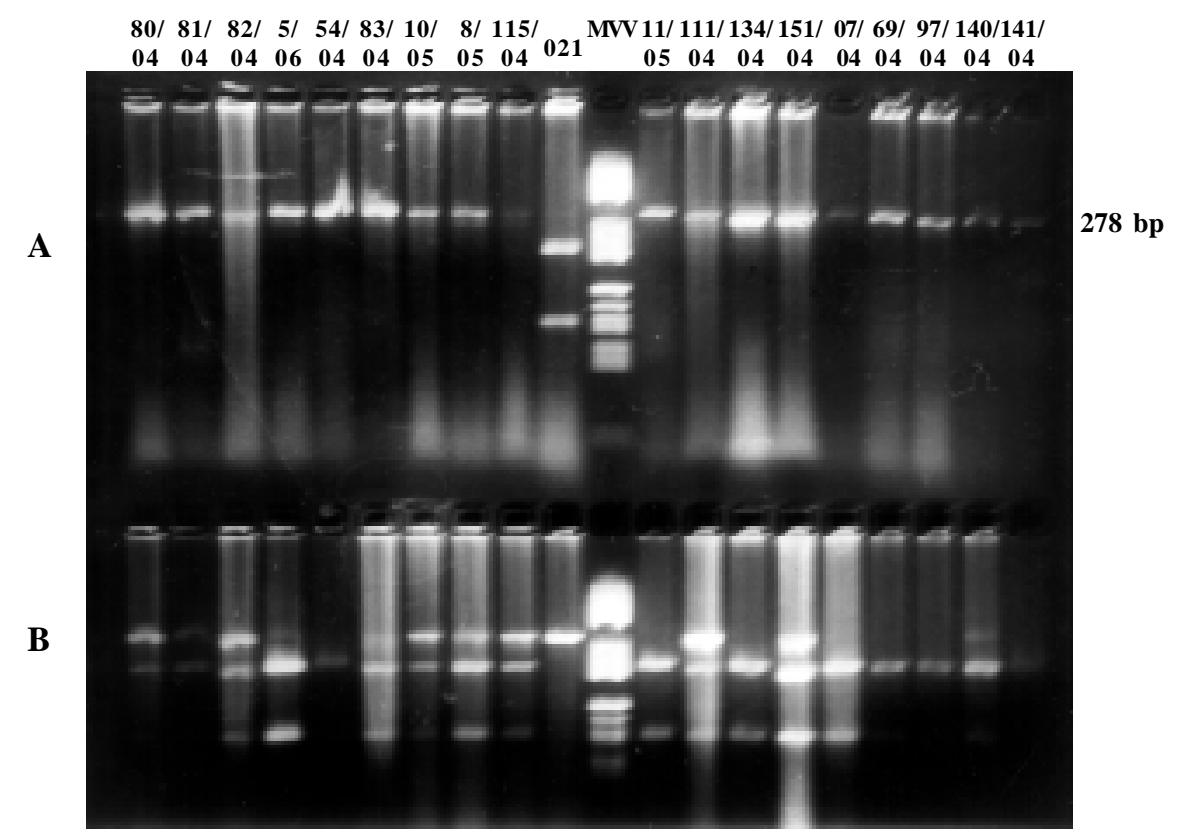

Fig. 2: restriction analysis of the polymerase chain reaction products obtained from each of the strains belonging to the first outbreak. A: digestion with Hind III; B: digestion with $B g l$ II; strain from Montevideo with known pattern NP5 (021); MW: PBR 322/Hae III.

in this study were obtained directly from clinical samples as well as from cell culture.

\section{DISCUSSION}

Sequence analysis of numerous HRSV isolates, mostly group A, have shown extensive variability of the G glycoprotein (Cane \& Pringle 1991, Sullender et al. 1991, García et al. 1994, Cane \& Pringle 1995b ). Several features about HRSV evolution emerged from these studies: (a) viruses from antigenic group A belong to different lineages that correlate with previously identified genotypes (Cane \& Pringle 1992, García et al. 1994). Most epidemics are produced by viruses classified into more than one genotype. At a local level, replacement of predominant genotypes was observed during consecutive years (Cane \& Pringle 1995a); (b) HRSV genotypes have a worldwide distribution and viruses isolated in distant places and in slightly different years may be more closely related than viruses isolated in the same place on two consecutive days (Melero et al. 1997); (c) antigenic changes, detected with a panel of anti-G monoclonal antibodies, correlated with the position of viruses in the phylogenetic tree (García et al. 1994, Cane \& Pringle 1995b). However, the viruses used in those studies were isolated mainly in places of temperate climate (where annual outbreaks of HRSV occur in winter months) and in most cases in countries of high economic status (Melero et al. 1997). Very limited epidemiological data is avail-

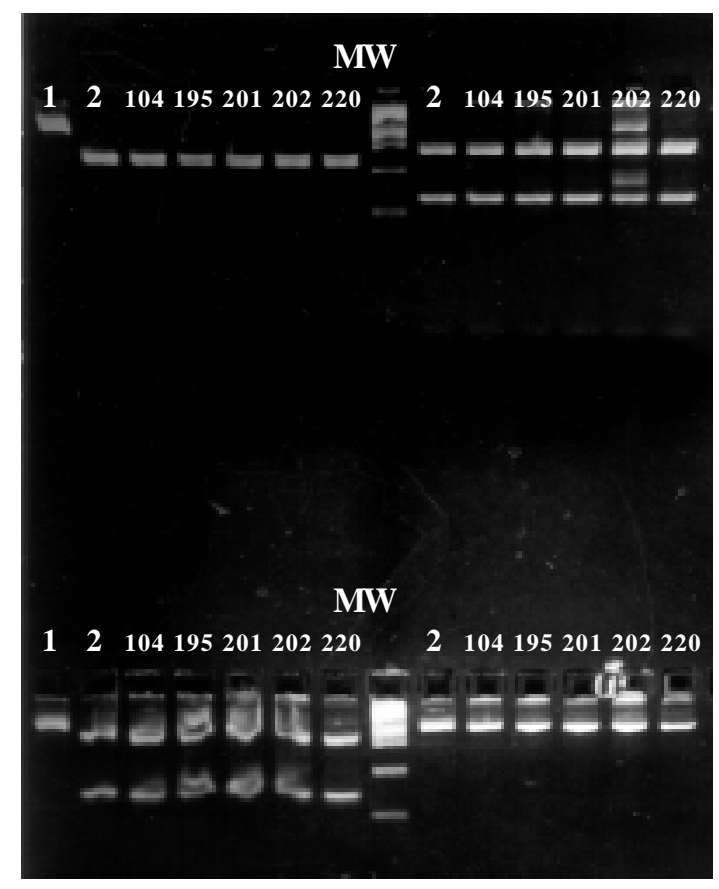

Fig. 3: restriction analysis of the polymerase chain reaction products obtained from each of the strains belonging to the second and third outbreaks. Lane 1: reference strain Long without digesting; Lane 2: reference strain Long digested; Lane 3 to 7: strains belonging of these outbreaks. Upper left square: digestion with Hae III. Upper right square: digestion with Rsa I. Lower left square: digestion with $B g l$ II. Lower right square: digestion with Hind III. 
able from tropical countries where HRSV infections may follow a different pattern (Heirholzer et al. 1994).

With regard to the above considerations and the reports made in previous studies by other authors, the most remarkable facts of our results are: (1) the strains analized in three consecutive outbreaks are identical using both methods; (2) the pattern obtained from the analyzed strains and by the two methods used, established a very closed relation between these strains and the standard Long strains, which is one of the oldest around the world (ends of the 50's).

In this work we combined the use of monoclonal antibodies and restriction analysis of PCR products for the select region of $\mathrm{N}$ gene to make a molecular characterization of three outbreaks of HRSV in Havana City.

All the isolated strains were identified as RS subgroup A by means of monoclonal antibodies and gave N gene fragment restriction pattern NP4. In our opinion, many factors have contributed to the peculiar behavior of the molecular epidemiology of this virus in Cuba.

After the end of the 50's, the exchange of people with others countries was extremely reduced due to economic, social and political reasons. This situation has continued for 30 years, reducing the probability of entrance of new strains. On the other hand, Cuba, as an island, does not share borders with any other country, which limits the entrance of people from other neighboring countries. Nevertheless, in the 90's, an outburst of the tourist industry took place in Cuba, but the most important fact is that this increase was observed in grownups and not in young children who constitute the natural reservoir of the virus.

All these geographical, social and economic factors could be the main cause of such peculiar behavior for the molecular epidemiology of this virus in our country.

It will be interesting to examine strains from Havana City and other Cuban regions in the same country in subsequent years to determine when and where a new pattern appear or reappear. In this sense it would be interesting to extend such molecular approach to other tropical countries even in distant geographical areas.

\section{ACNOWLEDGEMENTS}

To Dr German Roges and Orquidea Biart for critical review of the manuscript.

\section{REFERENCES}

Anderson LJ, Heirholzer JC, Tsou C, Hendry RM, Fernie BN, Stone Y, McIntosh K 1985. Antigenic characterization of respiratory syncytial virus strains with monoclonal antibodies. J Infect Dis 151: 626-633.

Cane PA, Pringle CR 1991. Respiratory syncytial virus heterogeneity during an epidemic: analysis by limited nucleotide sequencing (SH gene) and restriction mapping (N gene). J Gen Virol 72: 349-357.

Cane PA, Pringle CR 1992. Molecular epidemiology of respiratory syncytial virus: Rapid identification of subgroup A lineages. J Virol Methods 40: 297-306.

Cane PA, Pringle CR 1995a. Molecular epidemiology of human respiratory syncytial virus. Seminars Virol 6: 371-378.

Cane PA, Pringle CR 1995b. Evolution of subgroup A respiratory syncytial virus: evidence for progressive accumulation of aminoacid changes in the attachment protein. J Virol 69: 2918-2925.

Cane PA, Matthews DA, Pringle CR 1992. Analysis of relatedness of subgroup A respiratory syncytial viruses isolated worldwide. Virus Research 25: 1522.

Coates HV, Alling DW, Chanock RM 1966. An antigenic analysis of respiratory syncytial virus isolates by a plaque reduction netralization test. $A m J$ Epidemiol 89: 299-313.

Collins PL, Anderson K, Langer SJ, Wertz GW 1985. Correct sequence for the major nuclecapsid protein rnRNA of respiratory syncytial virus. Virology 146: 69-77.

Cristina J, López JA, Albo C, García-Barreno B, García J, Melero JA, Portela A 1990. Analysis of genetic variability in human respiratory syncytial virus by the Rnase A mismatch cleavage method: subtype divergence and heterogeneity. Virology 174: 126-134.

Garcia O, Martin M, Dopazo J, Arbiza J, Frabasile S, Russi J, Hortal M, Perez-Brena P, Martinez I, Garcia Barreno B, Melero JA 1994. Evolutionary pattern of human respiratory syncytial virus (Subgroup A): Cocirculating lineages and correlation of genetic and antigenic changes in the G glycoprotein. $J$ Virol 68: 5448-5459.

Garcia-Barreno B, Palomo C, Penas C, Delgado T, PerezBrena P, Melero JA 1989. Marked differences in the antigenic structure of human respiratory syncytial virus F and G glycoprotein. $J$ Virol 63: 925-932.

Heirholzer JC, Tannock GA, Heiholzer CM, Coombs RA, Kennett ML, Phillips PA, Gust ID 1994. Subgrouping of respiratory syncytial virus strains from Australia and Papua New Guinea by biological and antigenic characteristic. Arch Virol 136: 133147.

Kitchin PA, Bootman JS 1993. Quality control of the polymerase chain reaction. Med Virol 3: 107-114.

Kumar A, Lindberg N 1972. Characterization of messanger ribonucleoprotein and messanger RNA from KB cells. Proc Natl Acad Sci 69: 681-685.

Kwok S, Higuchi R 1989. Avoiding false positives with PCR. Nature 339: 237-238.

McInstosh K, Chanock RM 1990. Respiratory syncytial virus, p.1313-1351. In BN Fields, DM Knipe, PM Howley (eds) Fields Virology, Lippincot-Raven, Philadelphia.

Melero JA, García-Barreno B, Martinez I, Pringle CR, Cane PA 1997. Antigenic structure, evolution and immunobiology of human respiratory syncytial vi- 
rus attachment (G) protein. J Gen Virol 78: 24112418.

Mufson MA, Orvell C, Rafnar B, Norrby E 1985. Two distinct subtypes of human respiratory syncitial virus. J Gen Virol 66: 2111-2124.

Parrott RH, Kim HW, Brandt CD, Beem MO, Richardson L, Gerin JL, Chanock RM 1979. Respiratory syncytial virus, p. 695-708. In EH Lennette \& NJ Schmidt (eds), Diagnostic Procedure for Viral, Rickettsial and Chlamydial Infection, Amer Pub Health Ass, Washington, D.C.

Stoker NG 1990. The polymerase chain reaction and infectious diseases: hopes and realities. Trans $R$ Soc Trop Med Hyg 84: 775-758.

Sullender WM, Mufson MA, Anderson LJ, Wertz GM 1991. Genetic diversity of the attachment protein of subgroup B respiratory syncytial viruses. J Virol 65 : 5425-5434.
Taylor G, Stott EJ, Bew M, Fernie BF, Cote PJ, Collins AP, Hughes M, Jebbett J 1984. Monoclonal antibodies protect against respiratory syncytial virus infection in mice. Immunology 52: 137-142.

Valdivia A, Savon C, Chacón D, Sarmiento L, Morier L, Otero A, Soto Y, Oropesa S, Goyenechea A 1997. Analysis of respiratory syncytial virus in clinical samples by reverse transcriptase-polymerase chain reaction restriction mapping. Mem Inst Oswaldo Cruz 92: 389-393

Walsh EE, Schlesinger JJ, Brandis MW 1984. Protection from respiratory syncytial virus infection in cotton rats by passive tranfer of monoclonal antibodies. Infect Immun 43: 756-758.

Wright PA, Wynford-Thomas D 1990. The polymerase chain reaction: miracle or mirage? A critical rewiew of its uses and limitations in diagnosis and research. J Pathol 162: 99-117. 
476 Molecular Epidemiology of RSV in Havana City, Cuba - Angel Valdivia et al. 